\title{
Meningkatkan Prestasi Belajar Pkn Melalui Penggunaan Metode Pembelajaran Mind Mapping
}

\author{
I Made Retawan ${ }^{1}$ \\ 1SD Negeri 1 Serongga, \\ Gianyar, Indonesia \\ email: retawan235@gmaill.com
}

\begin{abstract}
Abstrak
Penelitian ini dilaksanakan di SD Negeri 1 Serongga di kelas I yang kemampuan siswanya untuk mata pelajaran PKN masih rendah. Tujuan penulisan penelitian tindakan kelas ini adalah untuk mengetahui apakah Metode Mind Mapping dapat meningkatkan prestasi belajar PKN siswa kelas I SD Negeri 1 Serongga. Metode pengumpulan datanya adalah tes prestasi belajar. Metode analisis datanya adalah deskriptif. Hasil yang diperoleh dari penelitian ini adalah Metode Mind Mapping dapat meningkatkan prestasi belajar PKN siswa kelas I SD Negeri 1 Serongga. Ini terbukti dari hasil yang diperoleh pada awalnya mencapai nilai rata-rata 64,23 , pada siklus I mencapai nilai rata-rata 69,61 dan pada siklus II mencapai nilai rata-rata 78,07. Kesimpulan yang diperoleh dari penelitian ini adalah Metode Mind Mapping dapat meningkatkan prestasi belajar PKN siswa kelas I SD Negeri 1 Serongga semester II tahun pelajaran 2018/2019.
\end{abstract}

Kata Kunci: Metode Mind Mapping, Prestasi Belajar PKN.

\begin{abstract}
This research was conducted at SD Negeri 1 Serongga in grade I, where the ability of students for PKN subjects was still low. The purpose of this classroom action research was to find out whether the Mind Mapping Method could improve the PKN learning achievement of grade I SD Negeri 1 Serongga students. The data learning method is a learning achievement test. The data analysis method is descriptive. The results obtained from this study are the Mind Mapping method can improve the learning achievement of PKN class I SD Negeri 1 Serongga students. This is from the results obtained at first reaching an average value of 64.23 , in my cycle it was proven that it reached an average value of 69.61 and in the second cycle it reached an average value of 78.07. The conclusion obtained from this study is that the Mind Mapping method can improve the learning achievement of PKN class I SD Negeri 1 Serongga semester II academic year 2018/2019.
\end{abstract}

Keywords: Mind Mapping Method, PKN Learning Achievement.

\section{Pendahuluan}

Sistem pendidikan di Indonesia ternyata telah mengalami banyak perubahan. Perubahan-perubahan itu terjadi karena telah dilakukan berbagai usaha pembaharuan dalam pendidikan. Akibat pengaruh itu pendidikan semakin mengalami kemajuan. Sejalan dengan kemajuan tersebut, maka dewasa ini pendidikan di sekolah-sekolah telah menunjukkan perkembangan yang sangat pesat. Perkemangan itu terjadi karena terdorong adanya pembaharuan tersebut, sehingga di dalam pengajaranpun guru selalu ingin menemukan metode dan peralatan baru yang dapat memberikan semangat belajar bagi semua siswa. Bahkan secara keseluruhan dapat dikatakan bahwa pembaharuan dalam sistem pendidikan yang mencakup seluruh komponen yang ada. Pembangunan dibidang pendidikan barulah ada artinya apabila dalam pendidiakn dapat dimanfaatkan sesuai dengan kebutuhan masyarakat dan bangsa Indonesia yang sedang membangun.

\footnotetext{
*Corresponding author.
}

Received 03 Februari 2020; Accepted 31 July 2020; Available online 1 September 2020 (C) 2020 MPI. All Rights Reserved 
Pada hakekatnya kegiatan beiajar mengajar adalah suatu proses interaksi atau hubungan timbal balik antara guru dan siswa dalam satuan pembelajaran. Guru sebagai salah satu komponen dalam proses belajar menganjar merupakan pemegang peran yang sangat penting. Guru bukan hanya sekedar penyampai materi saja, tetapi lebih dari itu guru dapat dikatakan sebagai sentral pembelajaran. Sebagai pengatur sekaligus pelaku dalam proses belajar mengajar, gurulah yang mengarahkan bagaimana proses belajar mengajar itu dilaksanakan. Karena itu guru harus dapat membuat suatu pengajaran menjadi lebeh efektif juga menarik sehingga bahan pelajaran yang disampaikan akan membuat siswa merasa senang dan merasa perlu untuk mempelajari bahan pelajaran tersebut. Guru mengemban tugas yang berat untuk tercapainya tujuan pendidikan nasional yaitu meningkatkan kualitas manusia Indonesia, manusia seutuhnya yang beriman dan bertakwa terhadap Tuhan Yang Maha Esa, berbudi pekerti luhur, berkepribadian, berdisiplin, bekerja keras, tangguh, bertanggung jawab, mandiri, cerdas dan terampil serta sehat jasmani dan rohani, juga harus mampu menumbuhkan dan memperdalam rasa cinta terhadap tanah air, mempertebal semangat kebangsaan dan rasa kesetiakawanan sosial. Sejalan dengan itu pendidikan nasional akan mampu mewujudkan manusia-manusia pembangunan dan rnembangun dirinya sendiri serta bertanggung jawab atas pembangunan bangsa. Depdikbud (1999).

Berhasilnya tujuan pembelajaran ditentukan oleh banyak faktor di antaranya adalah faktor guru dalam melaksanakan proses belajar mengajar, karena guru secara langsung dapat mempengaruhi, membina dan meningkatkan kecerdasan serta keterampilan siswa. Untuk mengatasi permasalahan di atas dan guna mencapai tujuan pendidikan secara maksirnal, peran guru sangat penting dan diharapkan guru memiliki cara/model mengajar yang baik dan mampu memilih model pembelajaran yang tepat dan sesuai dengan konsep-konsep mata pelajaran yang akan disampaikan. Untuk itu diperlukan suatu upaya dalam rangka meningkatkan mutu pendidikan dan pengajaran salah satunya adalah dengan memilih strategi atau cara dalam menyampaikan materi pelajaran agar diperoleh peningkatan prestasi belajar siswa khususnya pelajaran PKN. Misalnya dengan mcmbimbing siswa untuk bersama-sama terlibat aktif dalam proses pembelajaran dan mampu membantu siswa berkembang sesuai dengan taraf intelektualnya akan lebih menguatkan pemahaman siswa terhadap konsepkonsep yang diajarkan. Pemahaman ini memerlukan minat dan motivasi. Tanpa adanya minat menandakan bahwa siswa tidak mempunyai motivasi untuk belajar. Untuk itu, guru harus memberikan suntikan dalam bentuk motivasi sehingga dengan bantuan itu anak didik dapat keluar dari kesulitan belajar.

Berdasarkan pengalaman penulis di lapangan, kegagalan dalam belajar rata-rata dihadapi oleh sejumlah siswa yang tidak memiliki dorongan belajar. Sehingga nilai rata-rata mata pelajaran PKN sangat rendah yaitu mencapai 64,23 dengan KKM yang ditetapkan untuk mata pelajaran PKN adalah 70. Hal ini disebabkan karena guru dalam proses belajar mengajar hanya menggunakan metode ceramah, tanpa menggunakan alat peraga, dan materi pelajaran tidak disampaikan secara kronologis. Untuk itu dibutuhkan suatu kegiatan yang dilakukan oleh guru dengan upaya membangkitkan motivasi belajar siswa, misalnya dengan membimbing siswa untuk terlibat langsung dalam kegiatan yang melibatkan siswa serta guru yang berperan sebagai pembimbing untuk menemukan konsep PKN. Motivasi tidak hanya menjadikan siswa terlibat dalam kegiatan akademik, motivasi juga penting dalam menentukan seberapa jauh siswa akan belajar dari suatu kegiatan pembelajaran atau seberapa jauh menyerap informasi yang disajikan kepada mereka. Siswa yang termotivasi untuk belajar sesuatu akan menggunakan proses kognitif yang lebih tinggi dalam mempelajari materi itu, sehingga siswa itu akan meyerap dan mengendapkan materi itu dengan lebih baik. Tugas penting guru adalah merencanakan bagaimana guru mendukung motivasi siswa (Nur, 2001: 3). Untuk itu sebagai seorang guru disamping menguasai materi, juga diharapkan dapat menetapkan dan melaksanakan penyajian materi yang sesuai kemampuan dan kesiapan anak, sehingga menghasilkan penguasaan materi yang optimal bagi siswa. Berdasarkan uraian tersebut di atas penulis mencoba menerapkan salah satu metode pembelajaran, yaitu metode pembelajaran Mind Mapping untuk mengungkapkan apakah dengan metode Mind Mapping dapat meningkatkan motivasi belajar dan prestasi belajar PKN. Dari latar belakang tersebut di atas maka penulis dalam penelitian ini mengambil judul " Meningkatkan Prestasi Belajar PKN 
Melalui Penggunaan Metode Pembelajaran Mind Mapping Pada Siswa Kelas I SD Negeri 1 Serongga Semester II Tahun Pelajaran 2018/2019".

\section{Metode Penelitian}

Penelitian yang dilakukan termasuk penelitian tindakan. Oleh karenanya, rancangan yang khusus untuk sebuah penelitian tindakan sangat diperlukan. Penelitian tindakan didasarkan pada filosofi bahwa setiap manusia tidak suka atas hal-hal yang statis, tetapi selalu menginginkan sesuatu yang lebih baik. Peningkatan diri untuk hal yang lebih baik ini dilakukan terus menerus sampai tujuan tercapai (Suharsimi Arikunto, Suhardjono, Supardi, 2006: 6-7).

Dalam melaksanakan penelitian, rancangan merupakan hal yang sangat penting untuk disampaikan. Tanpa rancangan, bisa saja alur penelitian akan ngawur dalam pelaksanaannya.

Untuk penelitian ini penulis memilih rancangan penelitian tindakan yang disampaikan oleh Ebbut seperti terlihat pada gambar berikut.

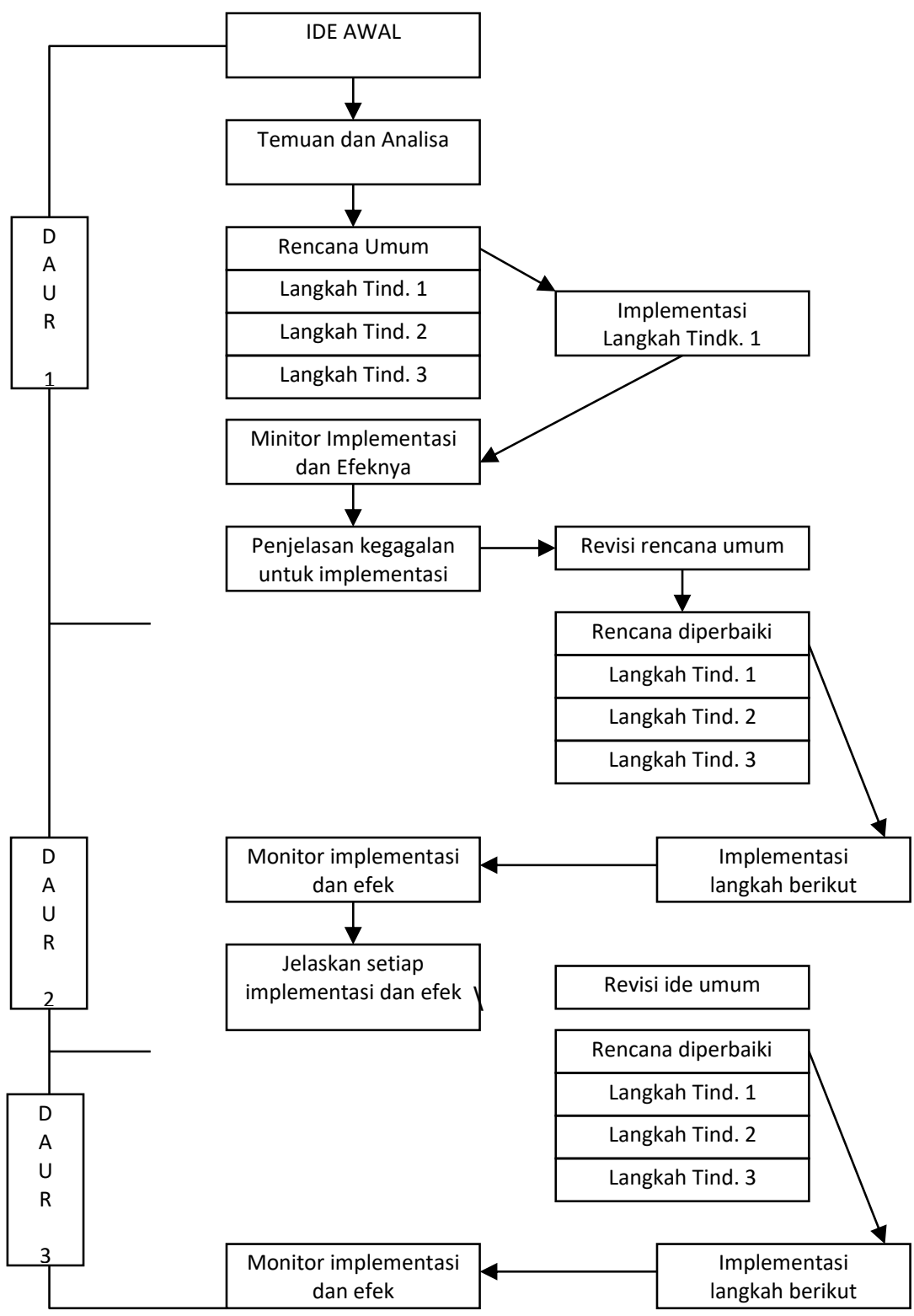

Gambar 01. Rancangan Penelitian Tindakan Model Ebbut (1985) 
Prosedur:

Sebagai alur PTK, Ebbut memberi contoh sebagai berikut.

Pada daur I dimulai dengan adanya ide awal akibat temuan dan analisis yang telah dilakukan. Setelah ada temuan tersebut dibuatlah perencanaan umum sesuai langkah yang direncanakan baik tindakan 1, tindakan 2 maupun tindakan 3. Sesudah membuat perencanaan, diimplementasikan dalam tingkat 1, dimonitoring implementasinya serta efeknya kemudian dijelaskan kegagalan-kegagalan yang ada selama implementasinya lalu dibuat revisi umum untuk perencanaan tindakan selanjutnya. Pada tindakan selanjutnya, perencanaan yang telah dibuat diimplementasikan, terus dimonitor implementasinya serta efek yang ada, dijelaskan setiap langkah implementasinya dan efeknya.

Setelah mengetahui bagaimana hasil dan efeknya, dibuat lagi perencanaan untuk tindakan selanjutnya. Demikian beranjut sampai menemukan hasil yang sesuai tujuan yang direncanakan. Pengumpulan data dalam penelitian ini menggunakan tes prestasi belajar. Tes prestasi belajar berupa tes soal isian maupaun esay. Untuk menganalisis data hasil penelitian ini digunakan metode deskriptif. Untuk data kuantitatif dianalisis dengan mencari mean, median, modus, membuat interval kelas dan melakukan penyajian dalam bentuk tabel dan grafik.

Indikator keberhasilan penelitian yang diusulkan dalam penelitian ini pada siklus I dan II mencapai nilai rata-rata 75,00 dengan ketuntasan belajar $85 \%$. dengan KKM yang ditetapkan untuk mata pelarajan PKN pada SD Negeri 1 Serongga adalah 70.

\section{Hasil Dan Pembahasan}

Mind Mapping atau Peta Pikiran adalah metode mempelajari konsep yang ditemukan oleh Tony Buzan. Konsep ini didasarkan pada cara kerja otak kita menyimpan informasi. Hasil penelitian menunjukkan bahwa otak kita tidak menyimpan informasi dalam kotak-kotak sel saraf yang terjejer rapi melainkan dikumpulkan pada sel-sel saraf yang berbercabang-cabang yang apabila dilihat sekilas akan tampak seperti cabang-cabang pohon.

Dalam membuat Mind Mapping juga disarankan menggunakan warna. Cara ini akan mempermudah Anda untuk menyusun pokok pikiran yang berbeda serta memperkuat efek asosiasi yang dibentuk oleh kata kunci-gambar-warna. Dengan cara yang lebih bebas, warnawarni, dan gambar, pemetaan pikiran menjadi berbeda dengan metode curah gagasan yang sudah dikenal luas. Hasilnya bisa mencengangkan karena dapat menemukan solusi inovatif untuk suatu Tema Utama yang menjadi fokus perhatian. Selain itu, pemetaan pikiran juga dapat mengidentifikasi masalah di bagian sub-tema yang disusun oleh kata kunci hasil curah gagasan.

Hasil pada penelitian ini dengan menerapkan metode mind mapping adalah sebagai berikut. Hasil yang diperoleh pada awal pembelajaran menunjukan perolehan nilai rata rata kelas hasil belajar PKN masih sangat rendah, yaitu dengan perolehan skor nilai secara klasikal yaitu 1670 dan rata rata kelas 64,23 , dimana siswa yang mencapai persentase ketuntasan belajar $42,30 \%$, dan yang tidak mencapai ketuntasan adalah $57,69 \%$, dengan tuntutan KKM untuk mata pelajaran PKN kelas I SD Negeri 1 Serongga adalah dengan nilai 70 . Rendahnya hasil yang diperoleh siswa karena guru masih menggunakan RPP konvensional dan kurangnya alat peraga yang digunakan, maka peneliti sangat perlu melakukan perbaikan pembelajaran pada siklus I dengan menggunakan Metode Mind Mapping.

Pada siklus I sudah diupayakan untuk perbaikan pembelajaran untuk meningkatkan hasil belajar PKN dengan menggunakan Metode Mind Mapping. Peneliti telah giat melakukan kegiatan yang susuai dengan kebenaran teori yang ada sehingga peneliti memperoleh hasil yang lebih baik dari proses awal, yaitu dengan rata rata nilai 69,61 dari jumlah nilai 1810 seluruh siswa di VI SD Negeri 1 Serongga dan prosentase ketuntasan belajarnya adalah $73,07 \%$, yang tidak tuntas adalah $26,92 \%$. Hasil ini belum maksimal, karena belum mecapai indikator keberhasilan penelitian yang mencanangkan dengan minimal prosentase ketuntasan belajar $85 \%$. 
Pada siklus II tindakan yang sangat maksimal dan pelaksanaan yang betul-betul mengikuti kebenaran teori sesuai dengan Metode Mind Mapping dalam pembelajaran PKN di VI SD Negeri 1 Serongga, dimana hasil yang diperoleh pada siklus II ini ternyata hasil belajar PKN meningkat secara signifikan dengan nilai rata-rata 78,07 dan ketuntasan belajarnya adalah $100 \%$.

Hasil penelitian ini diperkuat dengan hasil penelitian yang dilakukan oleh Setyarini (2019) dengan judul Metode Pembelajaran Mind Map Untuk Meningkatkan Prestasi Belajar Anak Didik Sekolah Dasar. Dalam penelitiannya disimpulkan bahwa metode pembelajaran mind map secara efektif dapat meningkatkan prestasi belajar anak didik sekolah dasar.

Selanjutnya penelitian yang dilakukan oleh Giriyanti dan Nina (2015) dengan judul Penerapan Metode Pembelajaran Mind Mapping Pada Mata Pelajaran Kearsipan Untuk Meningkatkan Aktivitas dan Hasil Belajar Siswa Kelas X Administrasi Perkantoran II DI SMKN 9 Semarang Tahun Ajaran 2014-2015. Berdasarkan hasil penelitian, dapat disimpulkan bahwa terjadi peningkatan keaktifan dan hasil belajar siswa pada mata pelajaran. Saran yang diberikan untuk meningkatkan keaktifan dan hasil belajar siswa di kelas adalah dengan cara siswa diminta lebih sering mengajukan pertanyaan dan sanggahan pada saat presentasi kelompok berlangsung.

\section{Simpulan}

Berdasarkan penelitian yang telah dilakukan dapat disimpulkan bahwa: penggunaan metode pembelajaran mind mapping secara efektif dapat meningkatkan Prestasi Belajar PKn siswa kelas I SD Negeri 1 Serongga semester II Tahun pelajaran 2018/2019.

\section{Daftar Pustaka}

Arends, Richard I. 2004. Learning to Teach. Sixth Edition. New York: McGraw-Hill

Arikunto, Suharsimi; Suhardjono; Supardi. 2006. Penelitian Tindakan Kelas. Jakarta: PT Bumi Aksara.

Azwar, Saifuddin. 2001. Tes Prestasi. Yogyakarta: Pustaka Pelajar.

Azwar, Saifuddin. 2003. Penyusunan Skala Psikologi. Yogyakarta: Pustaka Pelajar.

Busan, Tony. 2008. Buku Pintar Mind Map. Alih Bahasa Susi Purwoko. Penerbit: PT Gramedia Pustaka Utama. Jakarta.

Dahar, R. W. 1989. Teori-teori Belajar. Jakarta: Erlangga.

Dahar, Ratna Wilis. 1989. Teori-Teori Belajar. Jakarta: Penerbit Erlangga.

Daryanto. 1999. Evaluasi Pendidikan. Rineka Cipta: Jakarta.

Depdiknas, 2002a.Pedoman Umum Sistem Pengujian Hasil KBM Berbasis Kemampuan Dasar. Dirjen Dikdasmen.

Depdiknas,2002b. Pedoman Khusus Sistem Pengujian Hasil KBM Berbasis Kemampuan Dasar. Dirjen Dikdasmen.

Giriyanti, Indri dan Nina Oktarina. 2015. Penerapan Metode Pembelajaran Mind Mapping Pada Mata Pelajaran Kearsipan Untuk Meningkatkan Aktivitas dan Hasil Belajar Siswa Kelas X Administrasi Perkantoran II DI SMKN 9 Semarang Tahun Ajaran 2014-2015. Economic Education Analysis Journal Volume 4 Nomor 3.

Nur. 2001. Ilmu Pendidikan. Jakarta: Rineka Cipta.

Setyarini, Devi. 2019. Metode Pembelajaran Mind Map Untuk Meningkatkan Prestasi Belajar Anak Didik Sekolah Dasar. Jurnal IImiah "Pendidikan Dasar" Vol. VINo. 2 Juli $2018 .$. 